\title{
Green Marketing Dynamics by Consumers towards the Awareness, Purchase and Promotion of Green Products
}

\author{
Sravanthi, MBS \\ Research Scholar \\ Department of Business Administration \\ Yogi Vemana University \\ Kadapa - 516005, Andhra Pradesh, India \\ Dr. Amruth Prasad Reddy, A \\ Research Supervisor \\ Department of Business Administration \\ Yogi Vemana University \\ Kadapa - 516005, Andhra Pradesh, India
}

\begin{abstract}
The need of the hour is to protect the environment and to face the challenge of keeping consumers in fold. The green movement across the globe is spreading at a faster rate. Consumers occupy a central place since their awareness and motivation continue to drive change in market place significantly through the induction of eco-friendly products. Indian consumer in general when compared to the global land has always been less aware of environmental issues. Green marketing a popular concept is spreading in India at a faster rate creating awareness among the consumers about the need and necessity of protecting the environment. Awareness has to be created among consumers and marketers about deteriorating level environment causing heavy loss may be human arrival and nature loss. Further, already it has been warned that in next 5 years' time there may be further damage to be environment which may bring tragic consequences on human beings across the globe. Already the globe is experiencing severe global warming, greenhouse gas emission, water and air pollution. All these things occur only because of using natural resources at a faster rate. The green marketing incorporates a wide range of activities such as modification of the product, product development, change in packaging style, use of recycled paper as well as modifying advertisement etc. Green marketing is a holistic universal marketing concept wherein the production, marketing, consumption, disposal of products and services happen in way that is less detrimental to the environment with growing awareness. An awareness among the consumers and marketers has to create about the simple definition in economies. "Human wants are many but the nature is niggardly". The ungenerosity, reluctance to give has to be well understood in a positive sense. An attempt is made in this paper to study about environment degradation, awareness of eco-friendly products, promotion of green products and influence of social factors on purchasing decisions.
\end{abstract}

Keywords: Eco-friendly products, promotion, environment degradation, global warming, air pollution.

\section{Introduction}

The modern lifestyles and consumption patterns in the globalized scenario are major drivers of environmental damage. Marketing has been criticized for contributing to the environmental damage by insisting on consumption and as a result contributing to throw away society and emphasizing on consumption of short term consumer grants (Seyed Abdolmajid Khorshidi et.al., 2015). On the other side marketing can be viewed as sale of new lifestyle and brings a overall change in the consumption style to the ecologically more concerned consumers. Marketing concept underwent a sea of change and has developed and widened its scope towards ecological issues from focusing on production, transportation and exchange (Ladua, I .2008).

Green marketing a universally accepted concept refers to the process of delivering the higher standards of living through marketing of green products which are environmentally safe. Since resources are limited by nature and human wants are unlimited, it becomes a significant factor that marketers are supposed to use the scarce available natural resources to the best extent without allowing waste as well as attainment of organizations goals. Green marketing and green products are the suitable strategies that are used by firms to increase competitive advantage and stand a chance of satisfying the consumer needs. The change in the attitude of consumers awareness to protect environment and raising awareness to buy only ecological products have increased the concern towards "environmentalism" across the world. Therefore, many firms across the globe have already begun to make and distribute only green products. 


\section{Statement of the problem}

The further degradation of environment causes losses and may end in excess rains, cloud burst, excessive global warming, destruction of ozone layer and the health of qualitative life of consumers may be severely affected. The recent heavy down pour of rains in Kerala and Coorg district of Karnataka are the living examples of human destruction and rehabilitation takes a couple of years. The environment protection through consuming only ecoproducts are going to be crucial in creating successful environmental strategies and in assisting the business firms and economies towards environmental sustainability. To attain sustainability of humankind green marketing practice is needed in the society.

The ecological issues are since getting worse, the consumers concern about the environment protection have led to the diversification in the buying approach towards green lifestyle. Therefore, business houses persuading relevant data to develop potential ecological approaches in the green marketing industry. Green marketing and green product development are useful techniques that are used by firms to increase competitive advantage and stand a chance of gaining consumer satisfaction in order to achieve firms mission and vision.

The ecological impacts have altered the relationship between human \& organizations and obviously environment significance has been redefined. Consequently, new perception emerged on the issues like environmental friendly products, recyclability waste reduction, the associated cost with pollution and the price value relationship of environmentalism. Furthermore, pressure from different stakeholders, government, global environmentalists, NGOs and consumers is put on the retailers which in turn place the retailers to be watchful, get a touch with latest developments. Governments, on the one hand is taking strict action on the violation of environment norms and on the other hand, consumers are outspoken regarding their environment friendly products and in many cases consumers are ready to pay premium and ready to buy high priced green products.

\section{Review of literature}

Shruthi P Maheswari (2014) is of opinion that there exist a gap between consumers' beliefs and behaviors over being green. The researcher has highlighted various aspects of consumer behavior and shown that consumer preference for greener goods could be influenced by marketing. Pro-environmental values are more likely to result in more proenvironmental behavior when values and beliefs are specific enough, the green action aligns with consumers subjective interests and product attributes are positively perceived. Further, the researcher has stated that the consumer trust the performance of well-known brands.

Joshi et.al, (2015) expressed that governments in various countries across the globe are beginning to show concern towards the threats like global warming, expanded environmental pollution, decline in flora and fauna to their business activities. This concern has led to the nation of "sustainable development" which emphasizes the need to promote sustainability and minimize the harmful impacts on the environment and society.

Jeevarathnam P. Govenderetal. (2016) have stated that respondents in South Africa displayed high knowledge levels of green marketing and environmental deterioration. It was found in their study that there was no significant relation between gender and awareness of green products. It emerged that respondents strongly felt that green marketing influenced their buying behavior, and there was no significant correlation between age and green marketing motivating consumers to change their consumption behavior. Further, they have stated that most of the respondents felt that green products were healthy, good for the environment and are superior to traditional products.

Sujit, T.S (2017) highlighted that people have awareness about the eco-friendly products and they show a positive attitude towards green marketing and green products. But awareness should be created about wide variety of products of eco-friendly. The researcher has stated that consumers in Kerala are less likely to buy green products if they are more expensive. The author suggested that efforts should be made to reduce the price of eco-friendly products.

Papads, K.K. et.al. (2017) stated that brand value increases with the implementation of green marketing principles. Further, they have stated that the company increases the value of its products, gains competitive advantage, improves the image of business, gets new market and is ready to go with environmental pressures of stakeholders. The authors have stated that the ideas of building brand on values related to environmental and social performance is connected to three factors viz., image of the green mark, fulfillment of the expectation of green promises and creditability.

Arathi et.al. (2018) research findings reveal that green marketing is beneficial to both firms and environment as it has full of benefits. Marketers should not only focus on its initial huge investment, instead they should focus on brand, long term growth and future dividends. The researchers tell that green marketing definitely helps the firm in earning trust of consumers by satisfying their needs. They have suggested that marketers need to understand the implication of green marketing. 


\section{Objectives of the study:}

To study the demographic profile of respondents.

To analyze the respondents awareness of environmental degradation and awareness of eco-friendly products.

To analyze the mode of promoting green products.

To study the influence of social factors on purchase of green products by respondents.

\section{Hypotheses:}

* H01: The demographic profile of respondents is not supporting green marketing and purchase of eco-friendly products.

* H02: Respondents are not aware of environmental degradation and not aware of eco-friendly products.

* H03: There is no promotion of green products.

* H04: Social factors are not influencing the purchase of green products.

\section{Research methodology}

A well drafted questionnaire was administered as schedule telling into all (1) literacy rates (2) avoiding non-response (3) to save time and resources. Before the administration of questionnaire as schedule a pilot study was conducted and necessary changes are incorporated. The collected data was tested through quantitative metrics like chi-square and ANOVA for validity and to give a scientific touch to the data. The data collected was presented using appropriate Likert scale. The present study was conducted in Rayalaseema region of Andhra Pradesh.

\section{Sample, sampling techniques and data collection}

The sample of the study was decided by using the following formula suggested by Bill Godden. This formula is used when population size is greater than 5000 and infinite

Sample Size $(\mathrm{SS})=\mathrm{Z}^{2} \times(\mathrm{P}) \times(1-\mathrm{P}) \div \mathrm{C}^{2}$

Where,

$\mathrm{Z}=\mathrm{Z}$-value ${ }^{\mathrm{A}}$ (e.g. 1.96 for a confidence level)

$\mathrm{P}=$ Percentage of population picking a choice, expressed as decimal ${ }^{\mathrm{B}}$.

$\mathrm{C}=$ Confidence interval, expressed as decimal. (e.g. $0.04=+/-4$ percentage points)

A Z-values (Cumulative Normal Probability Table) represent the probability that a sample will fall within a certain distribution.

$1.645=90 \%$ Confidence level

$1.96=95 \%$ Confidence level

$2.576=99 \%$ Confidence level

Sample Size $=3.8416 \times 0.5 \times 0.5 / 0.0016=0.9604 / 0.004$

Sample Size $=600.25$ or 600 .

Convenient sampling technique was followed to collect the data from respondents. Primary data was collected through questionnaire and secondary data was compiled from journals, bulletins, websites and Andhra Pradesh governments' statistical abstracts. 600 samples were considered as per the formula and a sample plan was prepared and followed.

Sample Plan

\begin{tabular}{|c|c|c|c|c|}
\hline \multirow{2}{*}{ Districts } & \multicolumn{3}{|c|}{ Consumers selected store wise } & \multirow{2}{*}{ Total respondents } \\
\cline { 2 - 5 } & Kirana Stores & Dept. Stores & $\begin{array}{c}\text { Super and } \\
\text { hyper markets }\end{array}$ & \\
\hline Anantapur & 112 & 24 & 24 & 160 \\
\hline Chittoor & 112 & 24 & 24 & 160 \\
\hline Kurnool & 112 & 24 & 24 & 160 \\
\hline YSR Kadapa & 84 & 18 & 18 & 600 \\
\hline $\begin{array}{c}\text { Rayalaseema } \\
\text { Region }\end{array}$ & 420 & 90 & 90 & 120 \\
\hline
\end{tabular}

Source: Survey method. 


\section{Survey Findings}

Table - 1. Demographic profile of Respondents

\begin{tabular}{|c|c|c|c|c|}
\hline & $\begin{array}{l}\text { Demographic } \\
\text { Profile of } \\
\text { respondents }\end{array}$ & No & $\%$ & $\mathrm{X}^{2}$ Value \\
\hline \multirow{3}{*}{ Gender } & Male & 480 & 80 & \multirow{3}{*}{$\begin{array}{l}216^{*} \text { significant @ 5\% level Rejects } \mathrm{H}_{0} \text { that } \\
\text { there exists no significant variations in the data } \\
\text { and accepts the presence of variation. } \\
\mathrm{TV}=3.841 \text {. }\end{array}$} \\
\hline & Female & 120 & 20 & \\
\hline & Total & 600 & 100 & \\
\hline \multirow{7}{*}{$\begin{array}{l}\text { Age (in } \\
\text { years) }\end{array}$} & $21-25$ & 45 & 7 & \multirow{7}{*}{$\begin{array}{l}97.50 * \text { significant @ } 5 \% \text { level. Rejects the null } \\
\text { hypotheses that there exists no significant } \\
\text { variation in the data and accepts the alternative } \\
\text { that there exist variations in the data. . } \\
\text { TV }=11.070\end{array}$} \\
\hline & $26-30$ & 60 & 10 & \\
\hline & $31-35$ & 120 & 20 & \\
\hline & $36-40$ & 130 & 22 & \\
\hline & $41-45$ & 160 & 27 & \\
\hline & Above 45 & 85 & 14 & \\
\hline & Total & 600 & 100 & \\
\hline \multirow{7}{*}{$\begin{array}{l}\text { Educatio } \\
\text { n Level }\end{array}$} & SSC & 100 & 17 & \multirow{7}{*}{$\begin{array}{l}84.00 * \text { significant @ } 5 \% \text { level, Rejects } \mathrm{H}_{0} \text { that } \\
\text { there exists no significant variations in the data } \\
\text { and accepts the presence of variations in the } \\
\text { data. } \\
\mathrm{TV}=11.070 \text {. }\end{array}$} \\
\hline & Intermediate & 130 & 21 & \\
\hline & General Degree & 150 & 25 & \\
\hline & Post-Graduation & 100 & 17 & \\
\hline & Law graduates & 30 & 05 & \\
\hline & Professional Degree & 90 & 15 & \\
\hline & Total & 600 & 100 & \\
\hline \multirow{8}{*}{$\begin{array}{l}\text { Occupati } \\
\text { on }\end{array}$} & Government service & 90 & 15 & \multirow{8}{*}{$\begin{array}{l}254.0168^{*} \text { significant @ } 5 \% \text { level, Rejects } \mathrm{H}_{0} \\
\text { that there is no significant variations in the data } \\
\text { and accepts the } \mathrm{H}_{1} \text { that there is significant } \\
\text { variations in the data. } \\
\mathrm{TV}=12.592 \text {. }\end{array}$} \\
\hline & Private Service & 100 & 17 & \\
\hline & Agriculture & 210 & 35 & \\
\hline & Business & 70 & 12 & \\
\hline & Professional & 60 & 10 & \\
\hline & Self-employed & 40 & 06 & \\
\hline & Home maker & 30 & 05 & \\
\hline & Total & 600 & 100 & \\
\hline \multirow{7}{*}{$\begin{array}{l}\text { Monthly } \\
\text { Income } \\
\text { (in Rs.) }\end{array}$} & $<20000$ & 40 & 7 & \multirow{7}{*}{$\begin{array}{l}84^{*} \text { significant@5\% level, Rejects } \mathrm{H}_{0} \text { that } \\
\text { there is no significant variations in the data and } \\
\text { accepts the } \mathrm{H}_{1} \text { that there is significant } \\
\text { variations in the data. } \\
\mathrm{TV}=11.070\end{array}$} \\
\hline & $21001-30000$ & 60 & 10 & \\
\hline & $31001-40000$ & 150 & 25 & \\
\hline & $41001-50000$ & 160 & 27 & \\
\hline & $51001-60000$ & 110 & 18 & \\
\hline & 60001 and above & 80 & 13 & \\
\hline & Total & 600 & 100 & \\
\hline
\end{tabular}

Source: Field sources

Table - 1 highlights data about demographic profile of respondent consumers. There are 480 males and 120 females. To test the presence of variability chi-square test was performed. Chi-square rejects the null hypotheses that there exists no variation in the data and accepts the alternative, that there exist significant variations in the data. There are 160 respondents belonging to 41-45 years age, followed by 130 between 36-40 years, 120 between 31-35 years, 85 above 45 years, 60 between $26-30$ and 45 between $21-25$ years. To measure the variability in opinions expressed by respondents a null hypothesis that there exists no significant variation in the data was framed. For this purpose, chisquare statistical test was performed. Chi-square statistical test fails to accept the null hypotheses and accepts the alternative that there exist significant variations in the data.

There are 150 degree holders, 130 intermediate, 100 each SSC and post graduate degree holders. Further, there are 90 professional degree holders and 30 law graduates. To measure the variations in the data provided by respondents a null hypothesis that there is no significant variation in the data was framed. For this purpose, chi-square test was performed. Chi-square fails to accept $\mathrm{H}_{0}$ and accepts $\mathrm{H}_{1}$. 
There are 210 respondents of the sample doing agriculture and agriculturists live near to nature and agriculture, followed by 100 involved in private service, 90 government service, 70 doing business, 60 professional, 40 selfemployed and 30 home makers. To measure the variations in the opinions expressed by respondents a null hypothesis that there exist no significant variations in the data was framed. For this purpose, chi-square test was performed. Chisquare fails to accept $\mathrm{H}_{0}$ and accepts $\mathrm{H}_{1}$. There are 160 respondents who are getting monthly income in the range of Rs.40001-50000, followed by 150 respondents getting in between Rs.30001-40000, 110 getting in between 5000160000,80 are 60001 and above, 60 in between 20001 and 30000. To measure the variations in the opinions expressed by respondents a null hypothesis that there exists no significant variation in the data has framed. For this purpose, chisquare test was performed and it fails to accept $\mathrm{H}_{0}$ and accepts $\mathrm{H}_{1}$.

Table $\mathbf{- 2}$. Gender and awareness of green products

\begin{tabular}{|c|c|c|c|c|}
\hline \multirow{2}{*}{\multicolumn{2}{|c|}{ Gender }} & \multicolumn{2}{|c|}{ Awareness } & \multirow{2}{*}{ Total } \\
\hline & & Yes & No & \\
\hline \multirow{2}{*}{ Male } & Count & 430 & 50 & 480 \\
\hline & $\%$ within Gender & $89.58 \%$ & $10.42 \%$ & $100 \%$ \\
\hline \multirow{2}{*}{ Female } & Count & 90 & 30 & 120 \\
\hline & $\%$ within Gender & $75 \%$ & $25 \%$ & $100 \%$ \\
\hline \multirow{2}{*}{ Total } & Count & 520 & 80 & 600 \\
\hline & $\%$ within Gender & $86.67 \%$ & $13.33 \%$ & $100 \%$ \\
\hline
\end{tabular}

Source: Field Sources

\begin{tabular}{|l|l|l|}
\hline $\begin{array}{l}\text { Null } \\
\text { Hypothesis: } \mathbf{H}_{\mathbf{0}}\end{array}$ & There exists no significant variation in the data & Accept \\
\hline
\end{tabular}

Chi-Square test - Gender and awareness of green marketing.

\begin{tabular}{|l|c|c|c|}
\hline & Value & df. & TV \\
\hline Pearson's Chi-Square & 17.6682 & 1 & 3.841 \\
\hline
\end{tabular}

Table -2 reveals information regarding gender and awareness of green products. 430 males out of 480 respondents are aware of green products and 90 out of 120 female are aware of green products and the rest of them were not aware of green products. To measure the variability, a Chi-square test was conducted to test the relationship between the gender of respondents and awareness of green products. It was found that there is no significant relationship between the two variables $(\mathrm{P}>0.05)$ as reflected in the table -2 . The null hypothesis is accepted. It can be, therefore, concluded that there is no significant relationship between the gender of respondents and awareness of green products.

Table - 3. Respondents' awareness of eco-friendly products

\begin{tabular}{|l|c|c|c|c|c|c|}
\hline \multicolumn{1}{|c|}{ Drivers of awareness } & SA & A & N & DA & SDA & T \\
\hline Green products are more healthy & 52 & 38 & 5 & 7 & 5 & 107 \\
\hline $\begin{array}{l}\text { Green products are good for the environment } \\
\text { protection }\end{array}$ & 45 & 25 & 3 & 4 & 3 & 80 \\
\hline Green products are good quality & 48 & 35 & 2 & 3 & 2 & 90 \\
\hline Green products are better than standard products & 55 & 22 & 2 & 2 & 2 & 83 \\
\hline Green products are reasonable well priced & 43 & 26 & 3 & 4 & 3 & 79 \\
\hline Green products are easily accessible in stores & 44 & 25 & 4 & 3 & 2 & 78 \\
\hline $\begin{array}{l}\text { Green products are well promoted and effects } \\
\text { purchase decision. }\end{array}$ & 42 & 30 & 2 & 5 & 4 & 83 \\
\hline \multicolumn{1}{|c|}{ Total } & $\mathbf{3 2 9}$ & $\mathbf{2 0 1}$ & $\mathbf{2 1}$ & $\mathbf{2 8}$ & $\mathbf{2 1}$ & $\mathbf{6 0 0}$ \\
\hline
\end{tabular}

Source: Field Sources

Note: SA=Strongly Agree; A= Agree; $\mathrm{N}=$ Neutral; DA= Disagree; SDA=strongly disagree.

Hypothesis

\begin{tabular}{|l|l|l|}
\hline H0 & $\begin{array}{l}\text { There exist no significant variation in the data and respondents are } \\
\text { not aware of eco-friendly products. }\end{array}$ & Reject \\
\hline H1 & $\begin{array}{l}\text { There exist significant variation in the data and respondents are } \\
\text { aware of eco-friendly products. }\end{array}$ & Accept \\
\hline
\end{tabular}

ANOVA Table

\begin{tabular}{|l|l|l|l|l|l|}
\hline Source of & Sum of & Degrees of & Mean Sum of & F-Ratio & F Table at \\
\hline
\end{tabular}




\begin{tabular}{|c|c|c|c|c|c|}
\hline variation & Squares & Freedom (df) & Squares & & $5 \%$ \\
\hline $\begin{array}{l}\text { Between the } \\
\text { sample }\end{array}$ & 11186.1631 & $(5-1)=4$ & $\begin{array}{l}11186.1631 / 4 \\
=2796.54\end{array}$ & $\begin{array}{l}2796.54 / 12.75 \\
=218.82\end{array}$ & \multirow[t]{3}{*}{$\begin{array}{l}F(4,30) \\
=2.69\end{array}$} \\
\hline $\begin{array}{l}\text { Within the } \\
\text { sample }\end{array}$ & 383.4287 & $(35-5)=30$ & $\begin{array}{l}383.4287 / 30 \\
=12.78\end{array}$ & & \\
\hline Total & 11569.5918 & $(35-1)=34$ & & & \\
\hline
\end{tabular}

Source: Field Sources

ANOVA Analysis: The calculated value being 218.82 higher than the TV=2.69@5\% level of significance with df $=\mathrm{V}_{1}=4$ and $\mathrm{V}_{2}=30$ fails to accept $\mathrm{H}_{0}$ and accepts $\mathrm{H}_{1}$.

Table -3 highlights data about respondents' awareness of eco-friendly products. Out of 600 respondents 329 strongly agree over the drivers of awareness followed by 201 agreed, 28 disagree and 21 each strongly disagree and neutral. Out of 329 respondents who said strongly agree a majority of respondents 55 said about green products are better than the standard products, 52 about more healthy, 48 about green products are of good quality, 45 about good for environmental protection, 44 easily accessible in all stores, 43 reasonably well priced and 42 about well promoted and affects purchase decision. Out of the 201 respondents who agree, 38 said about more healthy, 35 about good quality, 30 well promoted, 26 about green products are available at reasonable price, 25 each about good for the environment protection and easily accessible in all stores, 22 about better than the normal products. 5 respondents out of 21 who stand neutral said about more healthy, 4 about accessible in all stores. 49 respondents either are disagreeing or strongly disagree. To measure the variation in the data, a null hypothesis that there exists no significant variation in the data was framed. For this purpose, ANOVA was performed and ANOVA fails to accept $\mathrm{H}_{0}$ and accepts $\mathrm{H}_{1}$. Therefore, it is concluded here that there exist significant variation in the data and respondents are aware of eco-friendly products.

Table - 4. Respondents' awareness of environmental degradation

\begin{tabular}{|l|c|c|c|c|}
\hline \multicolumn{1}{|c|}{ Respondents Opinion } & SA & A & N & T \\
\hline Environmental degradation increased in recent years & 600 & - & - & 600 \\
\hline Environment deteriorate further in next 5 years & 438 & 120 & 42 & 600 \\
& $(73 \%)$ & $(20 \%)$ & $(7 \%)$ & $(100 \%)$ \\
\hline
\end{tabular}

Source: Field Sources

Table -4 clearly spells out that all respondents are strongly agree that environmental degradation increased in recent years (Fig-1). Further, table-4 and fig-2 reveals data that there will be further deterioration in environment in next 5 years.

\section{Fig:1-Environmental degradation increased in recent years}

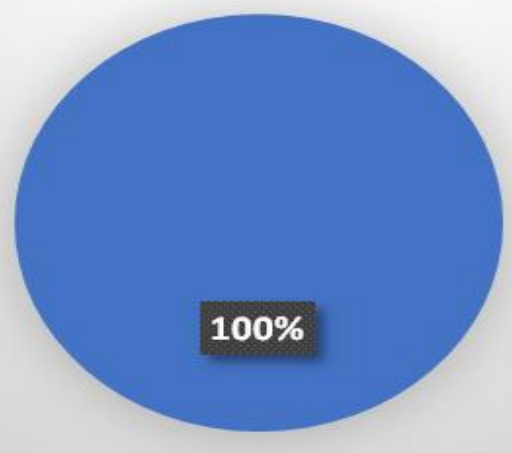

Source: Compiled from table -4 . 


\section{Fig:2-Environment deteriorate further in next 5}

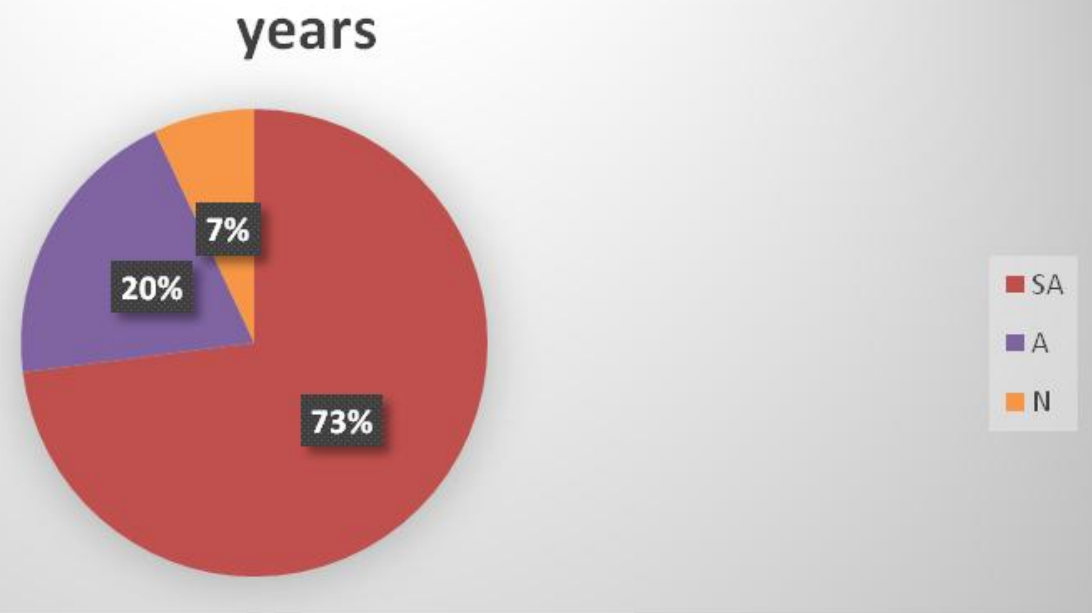

Source: Compiled from table -4 .

Table -5. Promotion of Green Products

\begin{tabular}{|l|c|c|c|c|c|}
\hline \multicolumn{1}{|c|}{ Mode of green product promotion } & SA & A & N & DA & T \\
\hline $\begin{array}{l}\text { Advertisement to green products creates } \\
\text { awareness of problems facing environment. }\end{array}$ & 79 & 45 & 8 & 10 & 142 \\
\hline $\begin{array}{l}\text { Advertisement motivates to buy eco-friendly } \\
\text { products }\end{array}$ & 60 & 35 & 5 & 7 & 107 \\
\hline $\begin{array}{l}\text { Word-of-mouth creates awareness and promotes } \\
\text { green products }\end{array}$ & 58 & 52 & 6 & 6 & 122 \\
\hline $\begin{array}{l}\text { Green labeling and packaging promotes the sale of } \\
\text { green products }\end{array}$ & 65 & 38 & 4 & 8 & 115 \\
\hline $\begin{array}{l}\text { Printed information on packaging helps to buy } \\
\text { only green products Total }\end{array}$ & 68 & 30 & 7 & 9 & 114 \\
\hline \multicolumn{1}{|c|}{$\mathbf{3 3 0}$} & $\mathbf{2 0 0}$ & $\mathbf{3 0}$ & $\mathbf{4 0}$ & $\mathbf{6 0 0}$ \\
\hline
\end{tabular}

Source: Field Sources

Note: $\mathrm{SA}=$ Strongly Agree; $\mathrm{A}=$ Agree; $\mathrm{N}=\mathrm{Neutral} ; \mathrm{DA}=$ Disagree.

\section{Hypothesis}

\begin{tabular}{|l|l|l|}
\hline H0 & $\begin{array}{l}\text { There is no existence of significant variations in the data and } \\
\text { respondents are unaware of mode of green products promotion. }\end{array}$ & Rect \\
\hline H1 & $\begin{array}{l}\text { There is existence of significant variations in the data and } \\
\text { respondents are aware of mode of green products promotion. }\end{array}$ & Accept \\
\hline
\end{tabular}

ANOVA Table

\begin{tabular}{|l|l|l|l|l|l|}
\hline $\begin{array}{l}\text { Source of } \\
\text { variation }\end{array}$ & \multicolumn{1}{|c|}{$\begin{array}{c}\text { Sum of } \\
\text { Squares }\end{array}$} & $\begin{array}{l}\text { Degrees of } \\
\text { Freedom (df) }\end{array}$ & $\begin{array}{l}\text { Mean Sum of } \\
\text { Squares }\end{array}$ & F-Ratio & $\begin{array}{l}\text { F Table at } \\
5 \%\end{array}$ \\
\cline { 1 - 1 } $\begin{array}{l}\text { Between } \\
\text { samples }\end{array}$ the & 12280 & $(4-1)=3$ & $\begin{array}{l}12280 / 3 \\
=4093.3333\end{array}$ & $\begin{array}{l}4093.3333 / 37 \\
=110.63\end{array}$ & \\
\cline { 1 - 1 } $\begin{array}{l}\text { Within } \\
\text { samples }\end{array}$ & 592 & $(20-4)=16$ & $\begin{array}{l}592 / 16 \\
=37\end{array}$ & & $\begin{array}{l}=(3,16) \\
=3.24\end{array}$ \\
\hline Total & 12872 & $(20-1)=19$ & & & \\
\hline
\end{tabular}

Source: Field Sources

ANOVA Analysis: The calculated value being 110.63 higher than the TV=3.24 at $5 \%$ level of significance with df $=\mathrm{V}_{1}=3$ and $\mathrm{V}_{2}=16$ fails to accept $\mathrm{H}_{0}$ and accepts $\mathrm{H}_{1}$.

Table- 5 reveals information about promotion of green products. 330 respondents out of 600 are strongly agreed over the mode of green products promotions, followed by 200 agree and 30 stood neutral and 40 disagree. 
Out of the 330 respondents who strongly agree, 79 said about advertisement creates awareness of problems facing environment, followed by 68 said about printed information on packaging helps to buy only green products, 65 about green labeling and packaging promotes the sale of green products, 60 about advertisement motivates to buy green products and 58 about word of mouth creates awareness and promotes green products. Out of 200 who said agree a majority of 52 said about word of mouth creates awareness and promotes green products, 45 said about advertisement creates awareness of problems faced by environment, 38 about green labeling and packaging green promotes the sale of green products, 35 about advertisement motivates to buy eco-friendly products. 70 respondents either stood as neutral or disagree over the mode of green products promotion. To measure the variations expressed by respondents a null hypotheses that there exists no significant variations in the data and respondents are not aware of the mode of green products promotion was framed. For this purpose, ANOVA was performed and ANOVA fails to accept $\mathrm{H}_{0}$ and accepts $\mathrm{H}_{1}$. Therefore, it is concluded that there exist significant variation in the data and respondents are aware of the mode of green products promotion.

Table - 6. Influence of social factors on green product purchase by respondents

\begin{tabular}{|c|c|c|c|c|c|}
\hline Social factors driving green product purchase & SA & $\mathbf{A}$ & SWA & DA & $\mathbf{T}$ \\
\hline Social variables & 70 & 38 & 15 & 8 & 131 \\
\hline Culture and subculture & 65 & 35 & 10 & 5 & 115 \\
\hline Social class & 60 & 40 & 9 & 4 & 113 \\
\hline Status maintenance & 73 & 32 & 13 & 6 & 124 \\
\hline Family influence & 72 & 25 & 13 & 7 & 117 \\
\hline Total & 340 & 170 & 60 & 30 & 600 \\
\hline
\end{tabular}

Source: Field Sources

Note: $\mathrm{SA}=$ Strongly Agree; $\mathrm{A}=$ Agree; $\mathrm{SWA}=$ Some What Agree; $\mathrm{DA}=$ Disagree.

\section{Hypothesis}

\begin{tabular}{|l|l|l|}
\hline H0 & $\begin{array}{l}\text { There exists no significant variation in the data and respondents } \\
\text { are not influenced by social factors }\end{array}$ & Reject \\
\hline H1 & $\begin{array}{l}\text { There exists significant variation in the data and respondents are } \\
\text { influenced by social factors. }\end{array}$ & Accept \\
\hline
\end{tabular}

\section{ANOVA Table}

\begin{tabular}{|l|l|l|l|l|l|}
\hline $\begin{array}{l}\text { Source of } \\
\text { variation }\end{array}$ & \multicolumn{1}{|c|}{$\begin{array}{c}\text { Sum of } \\
\text { Squares }\end{array}$} & $\begin{array}{l}\text { Degrees of } \\
\text { Freedom }(\mathrm{df})\end{array}$ & $\begin{array}{l}\text { Mean Sum of } \\
\text { Squares }\end{array}$ & F-Ratio & $\begin{array}{l}\text { F Table at } \\
5 \%\end{array}$ \\
\hline $\begin{array}{l}\text { Between } \\
\text { samples }\end{array}$ & 11800 & $(4-1)=3$ & $\begin{array}{l}11800 / 3 \\
=3933.33\end{array}$ & $\begin{array}{l}3933.33 / 18.75 \\
=209.87\end{array}$ & $\begin{array}{l}\text { F(3, 16) } \\
=3.24\end{array}$ \\
\cline { 1 - 4 } $\begin{array}{l}\text { Within the } \\
\text { samples }\end{array}$ & 300 & $(20-4)=16$ & $\begin{array}{l}300 / 16 \\
=18.75\end{array}$ & & \\
\hline Total & 12100 & $(20-1)=19$ & & & \\
\hline
\end{tabular}

Source: Field Sources

ANOVA Analysis: The calculated value being 209.87 higher than the TV=3.24 at $5 \%$ level of significance with df $=\mathrm{V}_{1}=3$ and $\mathrm{V}_{2}=16$ fails to accept $\mathrm{H}_{0}$ and accepts $\mathrm{H}_{1}$.

Table -6 reveals data about social factors influencing the purchase of green products by respondents. 340 respondents out of 600 strongly agree over the social factors driving the green product purchase, followed by 170 agree, 60 somewhat agree and 30 disagree. Out of 340 who strongly agree 73 said about status maintenance, 72 about family influence, 70 about social variables, 65 about culture and sub culture, and 60 about social class. Out of 170 respondents who said aware, 40 said about social class, 38 about social variables, 35 cultures and subculture, 32 status maintenance and 25 about family influence. Out of 60 who said somewhat aware, 15 said about social variables, 13 each status maintenance and family income, 10 about culture and subculture and 9 about social class. To measure the variability in the opinions expressed by respondents, a null hypothesis is that there exists no significant variation in the data and respondents are not influenced by social factors was framed. For this purpose, ANOVA was performed and ANOVA fails to accept the $\mathrm{H}_{0}$ and accepts $\mathrm{H}_{1}$. Therefore, it can be concluded here that there exist significant variation in the data and social factors drives green product purchase by consumers.

\section{Conclusion}

The exploratory study sought to probe the dynamics by consumers with special reference to retail markets of Rayalaseema region of Andhra Pradesh. 
Respondents displayed high knowledge of green marketing and environmental deterioration. It was found that there was no significant relationship between gender and awareness of green products. Majority of the respondents found that green products are healthy, good for environment and are better than traditional products. Respondents were influenced by promotion for green products and felt packaging, labeling and product information strongly influenced their purchase decision. Further, the respondents have knowledge of social factors influencing the purchase of green products. The agrarian community who lives nearby nature and agricultural land are better aware of environmentalism and its effects if environment protection is ignored.

\section{References}

Arathi Somala., and Mehal Kumar Patel, (2018). Green marketing in India. International Journal of Engineering technology and science and research, 5 (1), 739-748.

Bill Godden,(2004)."Sample size formulas'. www.williamgodden.com/samplesizeformula.pdf.

Jeevarathnam P. Guvender, and Tushya L. Guvender. (2016). The influence of green marketing on consumer purchase behavior. Environmental Economics, 7(2), 77-85.

Joshi, Y., and Rahman, Z. (2015). Factors affecting green purchase behavior and future. International Strategic Management Review, 3, (128-143).

Ladua, I, (2008). Gaining competitive advantage through customer satisfaction, trust and confidence in consideration of the green marketing. M.S. Thesis, University of GAVLE, Sweedan.

Papadas, K.K., Avlonitis, C.J., and Carrigan, M. (2017). Green marketing orientation, conceptualization, scale development and validation. Journal of Business Research, 80, 236-246.

Seyed Abdolmajid Khorshidi, Majid Etehady. (2015). Green Marketing: A System Dynamics Approach. International Research Journal of Applied and Basic Sciences, 9(5), 747-756.

Shruti, P Maheswari. (2014). Awareness of green marketing and its influence on buying behavior of consumers: special reference to Madhya Pradesh, India. AIMA journal of management and research, 8 (1/4), ISSN 0974-497. P.N.N. article No.3

Sujit, T.S. (2017). Awareness of green marketing and its influence on buying behavior of consumers in Kerala. International Journal of Scientific Research and Management, 5 (7), 6156-6164. 